\title{
Margaret McCartney: A summary of four and a half years of columns in one column
}

\author{
Margaret McCartney general practitioner
}

Glasgow

1.Screening is only for people with no symptoms. If you have symptoms it's not screening.

2.Screening is often counterintuitive. False positives proportionately rise when prevalence falls.

3. "Case finding" is the recourse of those who do non-evidence based screening but can't seem to admit it.

4.Inadequately tested tech can do as much harm as inadequately tested medicine.

5.The NHS is a pie. If you ask the NHS to do more without making the pie bigger, something else won't get done.

6.Apparent problems are fixed more effectively when they're first understood.

7.A system that uses blame to attempt improvement is likely to make good professionals miserable and leave.

8.Earlier isn't necessarily better. Lead time bias and overdiagnosis create mirages and do harm.

9.If it's not evidence based it might as well be homeopathy.

10eremy Hunt was not my favourite health secretary.

1P.overty kills. Statins do not effectively treat poverty.

12.ycling is fantastic. Cities that make cycling easy and safer are healthier cities.

13.ood should be pleasurable, and there are various ways to lose weight. Studies of diets are often flawed. Beware of people touting "simple" solutions and diet books.

14Many people seek to make money from those who don't understand science. Doctors should call out bollocksology when they see it.

13.rivate companies promising fast access to GPs in exchange for discontinuity of care may result in the fulminant collapse of NHS general practice.

16umans make mistakes. Honesty breeds forgiveness and better practice. 17owever, repeating policy errors is unforgivable if predictable. Health policy needs an "evidence desk" to critically review and stop avoidable errors. I make an ongoing offer to any government to staff that desk.

18eep your "thank you" cards. They will sustain you through your darkest days.

19.1e need to know the absolute risk. What's the all cause mortality? There's no use not dying from a disease if the treatment kills you.

20Ne should aim not to "raise awareness" but to improve knowledge.

2Everyone in healthcare should make a public declaration of interests. Charities, think tanks, and pressure groups should tell us where they get their money.

22.olitical in-fighting over the NHS wastes time, money, and morale. We should seek cross party cooperation, use evidence, and acknowledge uncertainty in decision making.

23.eople should be offered interventions and be given help to make decisions. Doctors should be judged on how helpful they are, not the decision made.

24.inancial incentives have caused a needless professional crisis in medicine.

25Appraisal is bunk.

26.he General Medical Council—a charity-pays for private health insurance and non-evidence based health screening for its staff. We doctors pay for this. It is a disgrace.

2Xystematic reviews usually shed more light than heat.

28:alse promise increases with the opportunity for profit.

29arkets in medicine increase demand and make people into patients needlessly, while those who need to be patients can't access care: the patient paradox.

30Ne're all going to die: CPR isn't good treatment for many. Citizens should know that, unless they opt out, they've been opted in. 
31.ess medicine may be better treatment. It can often feel risky to deprescribe, even though it shouldn't.

32Ne need \#alltrials reported.

33Appalling workloads that are neither appealing or safe will not be cured with more "resilience."

34 Medicine is a tough, unglamorous, difficult job which, with understaffing and austerity, often feels impossible to do well.

35Medicine is an absolutely brilliant job, and having long term relationships with patients and families is one of the most joyous and fulfilling aspects of work. 38eing a columnist has been great fun. The emails have (mostly) been a delight. But here I stop. Thank you to my editors, who are patient, kind, and clever; and thank you for reading.

Competing interests: See www.bmj.com/about-bmj/freelance-contributors/margaretmccartney.

Provenance and peer review: Commissioned; not externally peer reviewed.

Published by the BMJ Publishing Group Limited. For permission to use (where not already granted under a licence) please go to http://group.bmj.com/group/rights-licensing/ permissions 